\title{
A LITURGIA DA ESCOLA MODERNA: SABERES, VALORES, ATITUDES E EXEMPLOS ${ }^{1}$
}

\author{
Carlota Boto \\ Universidade de São Paulo, Brasil.
}

\section{Resumo}

A escola compõe, por seus fazeres e haveres, uma forma de liturgia. A compreensão da escola como um rito requer a observação dos movimentos internos constitutivos do cotidiano escolar, bem como a compreensão dos protocolos de ações projetadas para serem inseridas em práticas institucionais. Nesse sentido, as crianças em fila, a organização do espaço em classes seriadas, a construção de horários para abrigar as diferentes matérias e disciplinas do currículo, as interações do professor e dos alunos no espaço da sala de aula, as carteiras enfileiradas, o ponto registrado no quadro negro, tudo isso indicia ações e movimentos contidos no que compreendemos por vida escolar. Esta investigação debruça-se sobre alguns exemplos de modos de constituição da liturgia escolar, mediante $\mathrm{o}$ trabalho com fontes primárias consideradas oportunas para averiguar aspectos do cotidiano escolar: códigos de instrução pública, compêndios escolares de formação de professores, livros de leitura das escolas primárias, revistas de ensino e relatórios de inspeção. O período a que se circunscreve a documentação situa-se na segunda metade do século 19 e nos primeiros decênios do século 20. Procuramos recorrer a vestígios capazes de, emaranhados, proporcionarem elementos para reconstituição de rituais existentes nas escolas brasileiras - mais especificamente paulistas - e portuguesas. Compreendendo que se trata de um diálogo do mundo luso-brasileiro, a proposta foi a de estabelecer campos de aproximação entre as realidades dos dois países - com o perdão pela diacronia da longa duração. Não se pretende efetuar propriamente uma comparação entre as duas realidades - brasileira e portuguesa -, mas apenas articular relatos, entrecruzando rastros e procurando averiguar indícios que nos mostrem não apenas como a escola era em seu dia a dia mas como se supunha que ela devesse ser. Palavras-chave: escola primária, cultura escolar, rito, liturgia, história da educação.

\footnotetext{
${ }^{1}$ Texto originalmente apresentado como conferência de encerramento do $9^{\circ}$ Congresso Luso-Brasileiro de História da Educação: rituais, espaços e patrimônios escolares, ocorrido entre os dias 11 e 15 de julho de 2012 no Instituto de Educação da Universidade de Lisboa, organizado pela Sociedade Portuguesa de Ciências da Educação, pela SBHE e pela Anped. 


\section{THE LITURGY OF THE MODERN SCHOOL: KNOWLEDGE, VALUES, ATTITUDES AND EXAMPLES}

Abstract

School represents, due to the things that it does and the duties that it has, a type of liturgy. Viewing the school as a ritual requires the observation of the internal movements that make up the daily school routine, as well as an understanding of the protocols of actions designed to be inserted into institutional practices. In this sense, the children in line, the organization of the space into classes arranged into different grades, the construction of timetables to accommodate the different subjects and disciplines that make up the curriculum, the interaction between the teacher and the students within the space of the classroom, the rows of desks, the topic registered on the blackboard, all of this indicates actions and movements that are included in what we understand as being school life. This investigation addresses some examples of ways of constituting the school liturgy, by means of working with primary sources regarded as appropriate for ascertaining aspects of daily school life: public education codes, textbooks for training teachers, primary schools' reading books, teaching and inspection reports. The period that the documentation is limited to covers the second half of the $19^{\text {th }}$ century and the first few decades of the $20^{\text {th }}$ century. We seek to make use of tangled traces, capable of providing us with elements to reconstitute rituals existing in Brazilian schools - more specifically those in the State of São Paulo - and Portuguese schools. With the understanding that it deals with a dialogue of the Portuguese-Brazilian world, the proposal was to establish fields of approximation between the realities of the countries - with an apology for the change in the meanings of the words due to the long period of time. It is not exactly intended to achieve a comparison between the two realities - Brazilian and Portuguese -, but merely to examine reports, overlapping traces and seeking to identify evidence that shows us not just how school's day-to-day routine used to be, but to imagine what it must have been like.

Key-words: primary school, school culture, ritual, liturgy, history of education.

\section{LA LITURGIA DE LA ESCUELA MODERNA: SABERES, VALORES, ACTITUDES Y EJEMPLOS}

\section{Resumen}

La escuela compone, por sus tareas y obligaciones, una forma de liturgia. La comprensión de la escuela como un rito requiere la observación de los movimientos internos constitutivos de la vida cotidiana escolar, así como también la comprensión de los protocolos de acciones proyectadas para ser incluidas en prácticas institucionales. En ese sentido, los niños en fila, la organización del espacio en clases agrupadas por grados, la construcción de horarios para albergar las diferentes materias y disciplinas curriculares, las interacciones del profesor y de los alumnos en el espacio del salón de clases, los pupitres, el punto registrado en el pizarrón, todo eso muestra las acciones y movimientos contenidos en lo que conocemos como vida escolar. Esta investigación se inclina hacia algunos ejemplos como un modo de constitución de la liturgia escolar, mediante el trabajo con fuentes primarias consideradas oportunas para averiguar aspectos de la vida cotidiana escolar: códigos de instrucción pública, libros escolares para la formación de profesores, libros de lectura de las escuelas primarias, revistas de enseñanza y reportes de inspección. El período al que se circunscribe la documentación se ubica en la segunda mitad del siglo 19 y durante los primeros decenios del siglo 20. Buscamos recurrir a vestigios capaces de, enmarañados, proporcionar elementos para la reconstitución de rituales existentes en las escuelas brasileñas más específicamente las paulistas - y las portuguesas. Comprendiendo que se trata de un diálogo del mundo luso-brasileño, la propuesta fue la de establecer áreas de aproximación entre las realidades de ambos países - con el perdón de la diacronía de larga duración. No se pretende efectuar propiamente una comparación entre sus dos realidades - brasileña y portuguesa -, sino solamente articular relatos, entrecruzando rastros y buscando averiguar indicios que nos muestren no solo como era la escuela en su día a día, sino como se suponía que debería ser.

Palabras-clave: escuela primaria, cultura escolar, rito, liturgia, historia de la educación. 


\section{LA LITURGIE DE L'ECOLE MODERNE: SAVOIRS, VALEURS, ATTITUDES ET EXEMPLES}

Résumé

Par les responsabilités et faits qui s'y déroulent, l'école est une forme de liturgie. Pour comprendre l'école comme un rite, il suffit d'observer les mouvements internes constitutifs du quotidien scolaire ainsi que ses pratiques institutionnelles. Dans cette optique, les enfants en rangs, l'organisation de l'espace en séries de classes, la construction des horaires pour chaque matière, les interactions du professeur et des élèves dans la salle de classe, les cartables alignés, l'appel inscrit sur le tableau noir, toutes ces actions et mouvements forment ce que nous appellons la vie scolaire. Cette étude se penche sur certains exemples de modes de construction de la liturgie scolaire, à partir de sources opportunes du quotidien scolaire : codes d'instruction publique, abrégés de formation des maîtres, livres de lecture d'écoles primaires, revues d'enseignement et rapports d'inspection. Cette documentation se base sur une période allant entre la seconde moitié du 19e siècle et les premières décennies du $20^{\mathrm{e}}$ siècle. Ces vestiges nous fournissent des éléments utiles pour reconstituer les rituels existants dans les écoles brésiliennes (plus spécifiquement paulistes) et portugaises. II s'agit d'un dialogue du monde luso-brésilien, établissant des points de rapprochement entre les deux pays, et non d'une comparaison à proprement parler entre la réalité brésilienne et la réalité portugaise: l'articulation de récits, l'entrecroisement des traces et la recherche d'indices nous montrent non seulement comment était l'école au jour le jour mais aussi comment elle était supposée être.

Mots-clé: école primaire, culture scolaire, rites, liturgie, histoire de l'éducation. 


\section{A escola como cenário público}

idéia que eu vou desenvolver aqui é a de que a vida escolar se desenrola no
tabuleiro social como um rito, como uma liturgia. Há uma maneira de ser
escola, que se expressa mediante rituais, mobilizando sentimentos, experiências e símbolos. Há um script, uma coreografia, que a escola estrutura em seu dia a dia e com a qual apenas os que passam por ela se familiarizam. Nenhuma outra instituição no cenário social é capaz de ocupar esse papel. Mediante o que se poderia compreender por "linguagem performativa" (Johnson, 1997, p. 137), a organização escolar instaura significados por meio dos quais há sincronia e ritmo entre gestos e movimentos.

O meu propósito é o de averiguar alguns indícios de exemplos de constituição do que já foi caracterizado na literatura pedagógica como rito do ensino primário, abordando aqui a intersecção Portugal e Brasil. Pode-se, pois, dizer que a escola compõe, por seus fazeres e haveres, uma forma de liturgia - como já assinalaram, aliás, sob diferentes perspectivas, Fernando Catroga (1991), Julia Varela (1992), Joaquim Pintassilgo; Rui Afonso da Costa (2007). Devo dizer que este trabalho é tributário, nesse sentido, de investigação anterior, desenvolvida no âmbito do convênio Capes/Grices, que, sob liderança de Marta Carvalho e Joaquim Pintassilgo, facultou-nos o acesso a acervos portugueses.

A consulta abarcou documentos variados para averiguar algumas pistas nelas existentes do registro do cotidiano escolar. O conjunto de documentos vistoriados varia, basicamente, entre o século 19 e os primeiros decênios do século 20. Compreendendo que se trata de um diálogo do mundo luso-brasileiro, a proposta foi a de estabelecer campos de aproximação entre as realidades dos dois países em clivagem da longa duração. Não se pretendeu, contudo, efetuar comparação entre as duas realidades brasileira e portuguesa -, mas apenas articular relatos, entrecruzar rastros e averiguar indícios que nos mostrassem não apenas como a escola era em seu dia a dia, mas como se supunha que ela devesse ser. É preciso lembrar, com Fernando Catroga, que também na História da Educação "é no processo de elevação do traço a documento que o acontecido (nível ontológico) se transmuda, em termos epistemológicos, em fato histórico" (Catroga, 2009, p. 114).

Norbert Elias demonstra que o processo civilizador das sociedades ocidentais, basicamente a partir do século 16, desenvolveu parâmetros de racionalização dos gestos e das condutas, com o fito de estabelecer redes, elos, cadeias sociais, voltados para civilizar comportamentos. A educação, e mais especificamente a escola, tiveram papel importante nesse processo. Na compreensão de Elias (1993), as clivagens de distinção social passaram a ser progressivamente situadas a partir da regulação das atitudes das pessoas perante os outros. O processo civilizador, nesse sentido, fez com que passasse a existir, com força cada vez maior, um "controle mais complexo e estável da conduta [que] passou a ser instilado no indivíduo desde seus primeiros anos, como uma espécie de automatismo, uma auto-compulsão à qual ele não poderia resistir, mesmo que desejasse" (Elias, 1993, p. 196). Tal dinâmica, que, para Elias, principia na sociedade de Corte, terá prosseguimento na história da formação dos diferentes estados nacionais e tem, no limite, o efeito de racionalizar a esfera pública, organizar a distribuição das 
pessoas no jogo social, disciplinar mentes, corpos e corações, firmar atitudes e vincar posições de prestígio.

Inscrita em sociedades que pretendem estabelecer agendas para a civilização, a história da moderna escolarização corresponde a um lento processo de organização de estilos e de rotinas que perfazem, a seu modo, um jeito específico e característico de transmissão de saberes, de valores e de maneiras de agir. Ao buscar historiar esses traços, confrontamo-nos com a necessidade de apreender um dado arquétipo de interação de adultos com crianças. $E$, nessa interação, como já destacaram as teses do campo da história da infância, nomeadamente os trabalhos de António Gomes Ferreira (1996) e Moisés Kuhlmann (2000), há que se envolver cuidado, criação, trato, tato e formação. Existe, na dinâmica educativa, uma lógica interna que instaura regras, normas, leis e indicativos da vida escolar, com seus rituais e suas rotinas, com seus usos e seus costumes.

A escola, tal como ela se constrói no mundo moderno, pretende ser harmoniosa, tenciona criar a sincronia dos movimentos infantis, inclusive se, para isso, ela precisar ser rigorosa; inclusive se - com a missão de se tornar o que Justino Magalhães aqui, evocando Comenius, chamou de oficina de homens - ela precisar ser dolorosa. Cynthia Greive Veiga (2002) recorda, à luz do pensamento de Elias, que o modelo de civilização que se instala no Ocidente - e muito especificamente o modo como ele é apropriado no mundo luso-brasileiro - supõe a existência de formas de comportamento que são traduzidas a princípio como 'coerções externas' para depois tornarem-se interiorizada.

Se a cultura que a escola veicula é, em alguma medida, interna à própria experiência escolar, certamente há saberes, referências, modelos, que são provenientes do exterior, que têm a ver com determinações de poder, da política ou da inscrição social da ciência e que são apropriados pela instituição na forma de conteúdos e de ritos escolares. Há, por assim dizer, um efeito de "transposição didática" (Chevallard, 1991, p.39), que, como bem demonstra o trabalho de Vera T. Valdemarin (2004-2010), não é antagônico ao reconhecimento da tese segundo a qual a escolarização reinventa aquilo que é, aparentemente, transposto e transformado didaticamente. Por ser assim, é possível aferir a interação entre os conhecimentos e as informações dos quais a escola se apropriou, e reinventou a seu modo, e os protocolos e cerimônias cultivados no âmbito da própria sala de aula e que se dispõem como instâncias privilegiadas da forma de ser escola.

Inúmeros trabalhos já evidenciaram, empiricamente, a maneira pela qual há a institucionalização de rituais intrínsecos à escolarização. No movimento instituinte da tradição de pesquisa inaugurada no Brasil por Marta Carvalho, mediante o qual há mobilização do suporte teórico da história cultural para pensar os temas da historiografia da educação, as teses de doutorado de Diana Vidal (1995) e Luciano Mendes Faria Filho (1996), em meados dos anos 1990, já demonstraram o cariz litúrgico da escolarização. Ambos evidenciaram, na análise documental das instituições estudadas, que, por ser um rito, compreender a escola requer atentar para os movimentos internos constitutivos do cotidiano, bem como para os protocolos de ações e práticas escolares. Assim fizeram também, para o caso português, os trabalhos de Rogério Fernandes (1994), Áurea Adão (1997), Jorge Ramos do Ó (2003) e Maria João Mogarro (2001), dentre outros. Para o caso brasileiro, devemos ainda mencionar os trabalhos de Maria Lucia Hilsdorf (2011 
2002), Leonor Maria Tanuri (2000), Esther Buffa (2007), Carmen Sylvia Vidigal Moraes (2006), Marcus Levy Bencostta (2005), Maria das Graças Loiola Madeira (2008), Cleonara Maria Schwartz (2000), Esther Fraga Villas Boas (2002), Maria Juraci Maia Cavalcanti (2002) Diomar Motta (2004), Thaís Nívea Lima e Fonseca (2008), Cesar Castro (2007), Carlos Monarcha (1999), Eva Maria Siqueira Alves (2005), Ana Waleska Pollo Mendonça e Tereza Maria Fachada Levy Cardoso (2007) - dentre inúmeros outros.

Há gestos na escolarização que são inesquecíveis na liturgia da memória. As crianças em fila, a organização do espaço em classes seriadas, a construção de horários para abrigar diferentes matérias e disciplinas do currículo, as interações do professor e dos alunos no espaço da sala de aula, as carteiras enfileiradas, o ponto registrado no quadro negro, tudo isso indicia ações e andanças implicadas no que compreendemos por vida escolar. A representação ritual perpassa a documentação que fala sobre a vida nas escolas e indica claramente, como destaca Fernando Catroga, "o propósito de formar e de gerir os comportamentos" (1991, p. 409). Há um processo de repetição nos ritos, posto exatamente na dimensão performativa do script exigido de seus partícipes. Cabe recordar, todavia, que, se o professor pode ser considerado ator principal do rito pedagógico da escola, o aluno é protagonista involuntário do referido ato. Firma-se, pelo rito, uma pertença partilhada. Forma-se, por tal pertença, elos de comunidade e comunhão. Pode-se, pois, compreender que há um aspecto que abarca a fé, como se o universo simbólico da escolarização viesse regido pelo signo da crença e do cumprimento de expectativas.

\section{A liturgia escolar como instância de civilização}

É possível considerar que o atual discurso historiográfico da educação desmistifica certos "slogans educacionais" (Scheffler, 1974, p.46). Scheffler define slogans como "símbolos que unificam as ideias e atitudes chaves dos movimentos educacionais. Exprimem e promovem ao mesmo tempo a comunidade de espírito, atraindo novos aderentes e fornecendo confiança e firmeza aos veteranos" (Scheffler, 1974, p.46). Tais lugares de conforto do debate pedagógico são, por vezes, correntes nas escolas e nos órgãos governamentais responsáveis pela administração escolar e partem do suposto de que existem roteiros prévios inamovíveis, que constituem o programa desta ou daquela matéria. $O$ entendimento de que a escola elege certos saberes nos conduz à perspectiva de que há arbitrariedades na seleção dos conteúdos - o que possibilita, por conseguinte, a qualquer tempo, revisão dos mesmos conteúdos. A história da educação tem demonstrado, ademais, que a permanência de protocolos de interação, de modos de agir e de organizar espaços e tempos na vida escolar deriva - não como se poderia crer, da inércia dos professores - mas, primordialmente, das maneiras pelas quais esses saberes e fazeres são transmitidos de geração em geração, engendrando liturgias formativas.

A escola moderna lida com dois tipos de saberes. Há um aprendizado explícito de matérias do conhecimento, mas há também o aprendizado de formas de comportamento. Mannheim e Stewart (1977) nomeiam esses dois universos, respectivamente, de aprendizagem ativa e passiva; matérias e maneiras, poderíamos dizer. Como destacam os referidos autores, as relações interpessoais dos professores com seus alunos inscrevem-se em terreno fronteiriço. O lugar profissional do professor envolve, conforme sublinha Maria Teresa Santos Cunha, um conjunto de valores, de saberes, de normas de 
conduta, que os postará como "atores privilegiados na formação de mentes, de almas e de corações" (Cunha, 2007, p. 92). A escola primária, no percurso que a constitui, é cingida por uma tripla vocação: ensinar - a um só tempo - conhecimentos, valores e comportamentos.

Dizer que a escola ensina princípios e atitudes significa considerar também que, do ponto de vista educacional, o ensino parte de textos escritos, mas registra, para além disso, a acepção da exemplaridade como um código fundamental. A escola exemplifica os saberes e o escolar deve, na outra margem, valer-se da exemplaridade de seu mestre. Nos dois sentidos, portanto, a escola trabalha com a noção de exemplos. É preciso, ainda, que fique claro que, quando se diz que a escola tem por alicerce a base de um ensino manifesto dos saberes, de um ensino tácito de valores e de atitudes, quando se diz ainda que a escola fala por meio do exemplo, não se está a considerar o mérito nem dos saberes ensinados, nem dos valores ministrados, das atitudes inculcadas ou dos exemplos perfilhados. Justamente por ser um território inscrito em relações de conflito e em espaços de poder, é necessário indagar - como já observou algures António Nóvoa - a quais saberes, valores, atitudes e exemplos a escola tem historicamente se associado, naquilo que Nóvoa nomeará de "intencionalidade pedagógica" (Nóvoa, 1995, p. 13).

No Diccionario da lingua portugueza - publicado por Antonio Moraes Silva em Lisboa, em 1813, e dedicado ao Príncipe Regente - educação é um conceito definido como "criação que se faz de alguém, ou se lhe dá; ensino de coisas, que aperfeiçoam o entendimento, ou servem para dirigir a vontade, e também no que respeita ao decoro" (Diccionario, 1813, p. 647). Já ensino - para o mesmo dicionário - é "instrução, educação, urbanidade, direções, preceitos, máximas prudenciais e morais" (Diccionario, 1813, p. 707). Ensinar é mostrar o caminho a quem o ignora: ensinar é mostrar as coisas e os gestos.

\section{Instruções para mestres de primeiras letras}

$\mathrm{Na}$ Instrucção para os mestres de primeiras letras, impressa na Real Imprensa da Universidade, em 28 de setembro de 1824, há um roteiro das matérias que deveriam ser ensinadas, nas escolas de primeiras letras, para a formação de "cristãos, cidadãos justos e honrados e vassalos leais e de préstimo" (Instrucção, 1824, p. 3). Ao mestre-escola caberia ensinar doutrina e práticas da religião católica, a caligrafia, a pronúncia dos sons das palavras, a aritmética, a civilidade cristã e a ortografia "ou a arte de apresentar corretamente aos olhos as palavras por meio dos caracteres estabelecidos pelo uso" (Instrucção, 1824, p. 3). Diz ainda o texto que "por essas disciplinas mandam nossas leis polir a natural rudeza dos meninos e dispô-los para viverem com o decoro, próprio de sua condição, na Igreja e no Estado" (Instrucção, 1824, p. 3). A habilidade da leitura é tida por antecessora necessária da competência escrita: "depois de os meninos saberem já ler os impressos correntemente e com sentido, e só então que se deverão admitir as primeiras lições de escrita" (Instrucção, 1824, p. 5). Depois de conseguirem ler com distinção a letra impressa, aprenderão a "letra manuscrita ou de mão" (Instrucção, 1824, p. 6). Os manuscritos precisarão estar bem traçados para que as crianças sejam familiarizadas com o primeiro reconhecimento de textos: "começarão, pois, os meninos a ler por manuscritos bem legíveis e de boa ortografia e linguagem" (Instrucção, 1824, p. 6). O uso de bons traslados as auxilia a desenhar as primeiras letras, para depois serem ensinadas 
a juntar as letras nas sílabas, as sílabas nas palavras; "para o que se servirão de regrados de lápis ao princípio e de pautados de tinta ao depois" (Instrucção, 1824, p. 5).

A acepção de rito pode ser compreendida aqui como categoria primordial para representar as coisas que acontecem nas escolas. O modo de se compor as aulas articula-se como aquilo que Johnson (1997) qualifica como um dado "padrão de comportamento, usado para criar e manter o senso de conexão com o sistema social" ( $p$. 201). O rito reafirma uma pertença. Por intermédio do rito constrói-se a coesão e os laços de solidariedade social. Esta última é estruturada mediante crenças e hábitos herdados de uma dada tradição partilhada. Disse Fernando Catroga que o lugar social ocupado pelo rito é o de "religar os indivíduos entre si, através da produção de sentimentos de identidade e de pertença" (Catroga, 2005, p. 96). O protocolo de sua cerimônia tem por missão recordar à sociedade interações, aproximações simbólicas e significados repartidos.

\section{Os rituais escolares pelos registros legais}

Vem inscrito no Codigo de Instrucção Publica da Provincia de São Paulo, datado de 1857, um claro retrato de como deverá acontecer o ritual da escola primária. O silêncio, antes de tudo, precisa reinar entre as classes:

1) Assim que abrir a aula, o professor deverá fazer a chamada dos alunos, tomando nota dos presentes, registrando as ausências e os que chegam com atraso. Se o aluno demorar mais do que o normal para vir à escola, o pai deverá ser notificado.

2) Em seguida, o professor ou os alunos das classes mais adiantadas deverão tomar a lição dos alunos de $1^{a}$ e $2^{a}$ classes. Pelo menos, uma vez por semana, mesmo que tenha o auxílio de seu adjunto, o professor tomará, ele próprio, a lição desses alunos para verificar o seu adiantamento.

3) Os trabalhos da escola começam, portanto, "tomando as lições de moral, leitura, teoria de aritmética ou gramática" (Codigo, 1857, p. 30), principiando pelas turmas mais adiantadas para apanhar, em seguida, as turmas iniciais.

4) Após tomar as lições, o professor "explicará a lição do dia seguinte, e lhe passará o tema de aritmética ou gramática, que deverá ser escrito imediatamente dentro da escola. Enquanto o professor estiver tomando a lição das turmas superiores, as inferiores estarão estudando as suas, ou fazendo a escrita" (Codigo, 1857, p. 30).

5) Depois de realizarem a tarefa escrita, os alunos deverão estudar a lição seguinte.

6) "O professor passará a mesma lição para cada classe de cada turma, de sorte que a possa tomar ao mesmo tempo, dando cada aluno metade da lição ou toda. Quando, porém, um ou mais alunos se atrasarem de modo que não possam acompanhar a sua classe, será esta dividida em uma ou mais seções, cada uma das quais será composta dos que estiverem no mesmo ponto das matérias da classe" (Codigo, 1857, p. 30).

Além de tais orientações, consta do documento que "o professor fará reunir na escola o maior silêncio possível; somente falarão os alunos que estiverem dando a lição" (Codigo, 1857, p. 30). Além disso, nunca poderão sair da escola ao mesmo tempo dois alunos "enquanto o primeiro não houver voltado, ou sem licença do professor. Sobre a mesa deste, haverá um objeto, que será colocado de certo modo pelo aluno que sair, para servir de sinal" (Codigo, 1857, p. 30). Faz parte da liturgia escolar o reconhecimento dos alunos mais aplicados, que receberão um atestado honroso registrando a nota de seu 
louvor, mediante "duas ordens diversas de prêmios; uma para o mérito intelectual e outra para o mérito moral. Tanto uns como outros serão distribuídos na última sabatina do mês" (Codigo, 1857, p. 31). O professor precisará primar pela justiça, seja ao castigar, seja ao premiar. A idéia de classificação é, portanto, bastante presente, em um mecanismo claramente voltado para se aperceber dos melhores. A escola nomeia o aluno e pontua seus créditos. O julgamento da avaliação, em alguma medida, confere à escola seu caráter segregador: trata-se de alçar alguns pelo talento e deixar os outros à deriva de suas faltas.

No Estado de São Paulo, Relatórios de inspeção entre os anos 50 e 60 do século 19 - já trabalhados anteriormente por pesquisadores como Carlos Monarcha (1999) e Rita de Cássia Gallego (2011) - acusavam professores de ministrarem nas escolas públicas de primeiras letras exclusivamente a leitura, a escrita e as quatro operações fundamentais, deixando de ensinar Geometria, Gramática, a teoria da Aritmética, e, para as classes mais adiantadas, História e Geografia (Relatório, 1861, p. 18). O argumento usado pelos mestres para justificar sua incúria incidia no fato de os alunos abandonarem a escola por ordem de seus pais, que, em geral, não tinham dinheiro para lhes comprarem o livro pelo qual deveriam estudar. Os professores sequer haviam ouvido falar em métodos de ensino, empregando em suas aulas apenas o que o inspetor aqui nomeia de tradição: "quando tomam a regência de uma Cadeira, seu primeiro cuidado é, pois, ver se se recordam do modo por que seus próprios mestres os instruíram nas primeiras letras; depois começa o exercício mais ou menos semelhante ao desses mestres" (Relatório, s/d, p. 9).

Em Portugal de meados do século 19, também Antonio Feliciano de Castilho emitiu parecer sobre a falta de habilitação do "pessoal do magistério" (Castilho, 1909, p. 2). Para o educador, o programa de exames do magistério era a antítese das possibilidades de seus candidatos. Para ele, tratava-se de um problema circular: o programa era absolutamente enciclopédico e o saber real dos aprovados era insuficiente. Pagava-se mal aos professores e só concorriam, portanto, os que não eram capazes de conseguir outros postos profissionais. Qual seria, em tal cenário, a saída para que se pudesse, de fato, organizar um sistema de instrução pública em Portugal? Pelas palavras de Castilho, temos o que segue: "simplificar racionalmente o programa; ativar severidade nos exames; ampliar e muito os ordenados e mais vantagens aos professores. Não se exija dos candidatos senão o que é essencial que eles saibam ensinar" (Castilho, 1909, p. 18).

\section{Rabiscos de aula para a formação de professores}

Os livros dedicados à formação de professores, versando sobre o tema da pedagogia, consistem em argutos discursos sobre como ensinar a ensinar. São livros alçados, à partida, à condição de pedagogos. Veiculam um conjunto de orientações prescritivas, que pretendem dizer como organizar a aula, como ministrar as lições, como avaliar o aprendizado, como interagir com os alunos e como dispor do mobiliário escolar. Os livros de formação de professores são bastante minuciosos na organização de um modelo de compreensão pedagógica que tem na ideia de método sua força motriz.

Maria Helena Câmara Bastos explica que, no decorrer do século 19, os manuais para formação do professor primário contribuíram para a própria constituição da pedagogia como um campo específico do conhecimento, sendo, enquanto tal, 
instrumentos fundadores de práticas profissionais. Esses livros manifestaram crença ou fé no discurso da didática. Bastos (2011) compreende que a pedagogia dos manuais possibilita um código disciplinar que, por sua vez, "normatiza saberes, práticas e interioriza um habitus profissional que expressa continuidades e regularidades" (p. 505). Joaquim Pintassilgo observou, por sua vez, que os manuais de formação de professores do século 19 e princípio do século 20 caracterizam a Pedagogia, simultaneamente, como ciência da educação e como arte de ensinar. A ideia é de que se trata de uma "ciência aplicada" (Pintassilgo, 2011, p. 202), com a nítida valorização da "dimensão artesanal do trabalho docente" (p. 207). Marta Carvalho (2001; 2006), por seu turno, identifica estilos diferenciados nessa produção: tratados pedagógicos, livros de aconselhamento ou caixas de ferramentas.

O ponto de partida dos livros dirigidos ao magistério é o de que os modos de ensinar são excessivamente árduos, herméticos e ineficazes, sendo, necessário, pois, pensar em novas formas de compreender a ação do professor em sala de aula. Professores precisavam de escolas e escolas precisavam de livros. Tratava-se de encontrar, instaurar e perpetuar um método de ensino passível de ser considerado exitoso. Nessa condição, os modos de ensinar são dispostos como um roteiro de atitudes, que passam pelo conhecimento, mas que incidem, principalmente, sobre o campo dos valores. Ensinar o aluno requer o domínio de matérias e de prescrições de civilidade. Além disso, aprender a ensinar é também prestar atenção àqueles que ensinam bem.

Os autores dos manuais assumem, pois, a função de arautos da exemplaridade do magistério - como já assinalaram, aliás, os trabalhos de Vivian Batista Silva (2011) e de Thabatha Aline Trevisan (2011). O mundo da escola é composto por um repertório, uma linguagem e um conjunto de gestos organizadores dos rituais de ensinar e de aprender: a criança que levanta a mão para pedir o direito à fala; o professor que vistoria cadernos de alunos para conferir a lição; as crianças que copiam do quadro ou anotam a fala ditada; o professor que toma o ponto de leitura fazendo ler um por um; a divisão da sala em dois grupos para transformar a tabuada em exercício de disputa; o momento da preleção e o tempo da redação; a leitura em voz alta e a leitura silenciosa.

Miguel Alves Feitosa, autor do livro intitulado Duas palavras sobre o ensino, publicado em São Paulo no ano de 1892, acusa as escolas de seu tempo e o mau ensino nelas processado. Diz isso ao argumentar que o aluno, passando três ou quatro anos na vida escolar, terá pouco aproveitamento. Isso, no parecer do autor, leva as crianças - que haviam aprendido, espontaneamente, sem constrangimentos, um conjunto significativo de fatos e de ideias, mediante o "ver, ouvir e conversar" (Feitosa, 1892, p. 56) - a se transformarem em seres passivos; eles que eram tão ativos: "não perguntam mais; só respondem, quando interrogados; e se vão assim materializando por um ensino indigesto e pesado, onde só entra em ação a memória quase exclusivamente" (Feitosa, 1892, p. 56). Os meninos, nessas circunstâncias, não ousam mais perguntar. Tampouco dirigem questões a seus mestres: "perdem aquela ingênua e amável tagarelice que faz o seu encanto, para só se atordoarem a si e aos companheiros com essa monótona vozeria que todos conhecem de sílabas soltas e de leitura descompassada" (Feitosa, 1892, p. 57). Por perderem a curiosidade e o desejo de saber, deixam também de pensar por si próprios: "repetem apenas inconscientemente aquilo que pensam os mestres ou pensaram os autores que lêem ou decoram" (Feitosa, 1892, p. 57). 
Esta é, também, a perspectiva do dr. Feliciano Bittencourt, quando, no Rio de Janeiro, escreve seu Compêndio de pedagogia escolar. Na edição de 1908 há uma clara preocupação em tornar amenos os rituais do aprendizado do aluno. Haverá uma preleção, que norteará o cerimonial da aula. O livro, por sua vez, ensina ao professor as coisas que ele deverá ensinar aos alunos. Além disso, o livro traz a explicação matizada pelo exemplo. O exemplo faculta o entendimento e, simultaneamente, proporciona a repetição - necessária para a memória.

Quando lemos os livros dirigidos às escolas normais, invariavelmente indagamos: o roteiro de ações nele prescrito indicava o que deveria ser feito em sala de aula ou revelava o que os professores já faziam na época? Creio que podemos dizer que, em alguma medida, ambas as situações são contempladas: de fato, há uma nítida e explícita dimensão prescritiva, com o texto expondo argumentos para evidenciar a superioridade dessa ou daquela maneira de fazer as coisas em sala de aula. Por outro lado, é plausível supor que a prescrição contenha em si também o elemento da experiência exitosa. Muito provavelmente, portanto, esse ritual já era presente em alguma sala de aula. De todo modo, situava-se como ideal regulador de formas de ensino bem-sucedidas.

Augusto Coelho - autor cuja obra é, conforme já assinalou estudo de Marta Carvalho (2006; 2001), bastante utilizada em escolas normais portuguesas e brasileiras do início do século 20 - destaca a importância de se pensar a disciplina escolar à luz da formação das qualidades da vontade. Em Noções de pedagogia elementar, Augusto Coelho advoga a tese segundo a qual o objetivo prioritário da disciplina na escola será o de formar a criança para a constância de bons hábitos, adquiridos pela boa educação e capazes de firmar nos estudantes a educação da vontade. Educar a vontade, sob tal perspectiva, corresponderia a conter os impulsos e a levar o estudante a "conformar o seu querer com as leis e regras destinadas a conduzi-lo, quer, em geral, a respeitar os princípios da ordem, quer, em especial, a aplicar a atenção ao estudo" (Coelho, 1907, p. 70).

Os professores, enquanto "aplicadores práticos" (Coelho, 1907, p. 235) da pedagogia, necessitam desenvolver características concernentes aos modos de se comportar em sala de aula. No trato com as crianças o mestre deverá ser paciente e benevolente - capaz de angariar simpatia e afeto de seus alunos. Moralmente, é necessário que suas ações primem pela justiça e pela coerência entre o necessário rigor e a imprescindível brandura, intrínsecos à sua missão de educador. Finalmente, ele, professor, deverá se comportar de maneira a se tornar um exemplo para seus alunos.

Em Portugal, publicando na cidade de Coimbra a $6^{a}$ edição de sua obra Elementos de pedagogia, António Leitão destaca, de maneira próxima aos autores acima referidos, os atributos necessários ao ser professor: hábil, consciencioso, fisicamente robusto, disciplinado, dedicado e conhecedor de seu ofício e das matérias a serem ensinadas. Mais do que tudo isso, o profissional do ensino deve primar pelo "tato pedagógico" (Leitão, 1916, p. 32). Esse imprescindível requisito o "leva a conhecer sem esforço as necessidades do ensino, o grau de energia intelectual e moral dos seus alunos e os processos a empregar com o modo de ser psíquico próprio de cada um deles" (Leitão, 1916, p. 32). Para que as aulas não se tornassem rituais monótonos, enfadonhos e infrutíferos, com longas explicações, sugeria-se dinamizar o ensino mediante recurso à palavra do aluno que poderia interrogar e ser também a qualquer momento interrogado (Silva; Gallego, 2011). 
O método é compreendido como ordenamento do processo do ensino, de modo a que se possa organizar a ordem e a disposição mediante as quais se processará o trabalho com cada matéria. Os saberes são, assim, dispostos em fila, em um roteiro que classifica prioridades e seqüências didáticas e, por meio das estratégias e técnicas adotadas, são engolfados pelas lições e exercícios. Nesse sentido, a repetição das palavras, dos gestos e das atividades gerará ritos, cuja regularidade cotidiana engendra o modo de ser da sala de aula. Os ritos, desse modo, traduzir-se-ão como uma forma específica de se lidar com o tempo e com o espaço. É como se, pela liturgia da escolarização, houvesse interrupção do contínuo do tempo para se engendrar o lugar de um novo tempo, aquele do transcurso do ritual.

\section{Os compêndios da escola primária e a organização ritual da classe}

A análise histórica das cartilhas e dos livros de leitura deverá ter um enfoque específico, posto que, à primeira vista, não se tratará de expressar, de verter ou de adaptar didaticamente conteúdos derivados deste ou daquele campo do conhecimento. $\mathrm{O}$ ensino da leitura, aparentemente, tem uma autonomia que lhe é constitutiva. Porém, é possível verificar pela análise das cartilhas - como evidenciou a obra fundadora de Maria do Rosário Mortatti acerca do que ela nomeou de "sentidos da alfabetização" (2000, p. 1), que o debate acerca de métodos de se ensinar a ler e a escrever é orientado por discussões cuja matriz pode ser interna ou exterior à pedagogia - compreendidas, no caso, a partir das referências postas pelo estudo da língua. Daí a necessidade de proceder à adequação entre práticas de ensino, saberes dos livros escolares e conteúdos culturais que os referenciam.

Nesse sentido, é possível dizer que, se a cultura escolar tem realmente uma autonomia que lhe é constitutiva, ela também se traduz pela incorporação e recriação de conteúdos simbólicos que dizem respeito a campos variados da produção das ciências. Isso nos faz acreditar que a lógica interna da escolarização condiz com a identidade dessa confluência: são os usos escolares de linguagens provenientes dos diversos territórios do conhecimento humano que articulam e instituem os saberes ou conhecimentos presentes nos livros didáticos. Nesse sentido, se há elementos de apropriação, há também transposição de significados (Chevallard, 1991). Trata-se de uma transposição que altera o próprio sentido daquilo que foi recebido. Tudo o que se transpõe não chega da mesma forma ao lugar de destino. Ao ser transposto, um novo lugar se instituiu, um novo tempo se inaugurou, um novo conjunto de significados foi produzido, porque, no ato de ser transposto, o conhecimento foi reinventado.

O trabalho de Rosa Fátima de Souza (1998) já evidenciou a maneira pela qual se constituíram rituais escolares no interior da escola graduada paulista na virada do século 19 para o 20. Eram classes divididas em três turmas para o ensino da leitura, com alunos distribuídos por níveis de adiantamento. O professor enchia o quadro com palavras e frases e depois lia o que estava escrito. Cada criança era chamada para ler a lousa, para ler impressos e manuscritos. Toda lição estudada era, antes, explicada no quadro. Além disso, "ao iniciar a aula, o professor deveria recapitular as duas lições anteriores. Recomendava-se exigir dos alunos, na leitura, a expressão devida e a pronunciação correta, evitando-se, assim, vícios de linguagem. [...] Começava-se a leitura em voz alta pelos melhores alunos, visando educar o ouvido dos piores" (Souza, 1998, p. 199). 
O cenário da classe é, também, um elemento importante na compreensão da escola como um rito. O palco se dispõe para que a peça seja, todos os dias, ensaiada. Como já assinalou Margarida Louro Felgueiras, "a análise de diferentes tipologias de objetos, do mobiliário aos cadernos e canetas, dos materiais de laboratório aos manuais, revelam como os professores construíram tradições de ensino, que guiavam as suas práticas e que em alguns aspectos tendem a resistir no cotidiano" (Felgueiras, 2010, p. 31). Todos os dias, no mesmo tablado, tem lugar a liturgia do aprendizado da leitura, da escrita e do cálculo. No limite, é isso que se aprende no primeiro degrau da escolarização. Tão importante quanto isso é o aprendizado do bom comportamento civil, o qual constitui também matéria a ser perfilhada na escola primária. Ulysses Machado, em Livro de leitura para a segunda classe do ensino primário geral, destaca qual deveria ser o modelo do ritual escolar. O texto que dá início ao referido compêndio demonstra, de modo explícito, como o professor deve agir em sua classe. Demonstra, ainda, que a classe é, sob todos os pontos de vista, o lugar onde entra a luz:

Vou à escola. Cumprimento o senhor professor. Sento-me no meu lugar.
Ponho a mala na minha carteira. O senhor professor está no seu lugar. Vai
ao quadro preto. Escreve com o giz. Manda-nos preparar os nossos livros,
os nossos cadernos e os nossos lápis. Começa a lição. A sala de nossa
classe é espaçosa. Tem muitas janelas, por onde entram o ar e a luz. Os
alunos, quando entram na classe, abrem e fecham a porta devagar... O
senhor professor, do seu lugar, vê todos os alunos. As nossas carteiras
são cômodas. O quadro preto faz parte do mobiliário escolar. É de ardósia.
Nalgumas escolas é de madeira. O quadro preto é retangular. Está
colocado num cavalete. Os alunos escrevem, desenham e fazem contas
com giz no quadro preto. Algumas escolas têm dois e três quadros pretos
pendurados na parede. O senhor professor também escreve e desenha no
quadro preto. Devemos estar sempre atentos às explicações que o senhor
professor faz no quadro preto. (Machado, 1922, p. 4)

Inúmeros trabalhos, dentre os quais eu ressaltaria o de Maria Stephanou (1999; 2002; 2006), já demonstraram que a formação da moralidade é, no discurso pedagógico, acompanhada pela formação da civilidade. A civilidade, por sua vez, requer a formação de elementos distintivos que assegurem, no jogo social, o desempenho nas atitudes. Nas relações entre as pessoas, respeitar as regras da civilidade significa tornar-se amável, agir de modo a ser estimado pelo próximo, evitando, nesse sentido, desagradá-lo. A escola participa, por ser assim, da teia social que fabrica o que José Gonçalves Gondra chamou de "artes de civilizar" (2004, p. 1). Fazer do jogo social uma rede de interações, substituir a violência física pelo acordo da palavra requer, todavia, a formação do bem falar (Burke, 1995; 2005). Há uma compreensão de que, com dicção bem construída, com as maneiras e os gestos apropriados, se poderá formar a habilidade da fala pública. A fala pública é acompanhada, nesse sentido, por um conjunto de linguagens não verbais que, enquanto tal, precisarão ser aprendidas. Há, desse modo, um acervo significativo de obras destinadas a firmar na criança as posições e os modos pelos quais ela deverá se pronunciar futuramente na vida coletiva, na esfera pública. É o caso do compêndio também dirigido para uso das escolas publicado por Miguel Milano em São Paulo, no ano de 1914, sob o título Para bem ler e bem recitar. Esse livro, de acordo com o autor, versava sobre a ortofonia e era uma adaptação da obra de Jean Blaize intitulada Pour bien lire e bien reciter. O objetivo da ortofonia era corrigir os vícios de pronúncia, tais Hist. Educ. [Online] Porto Alegre v. 18 n. 44 Set./dez. 2014 p. $99-127$ 
como a gagueira, a hesitação, o cecear e o falar fanhoso. Pretendia auxiliar as pessoas a falar bem, destacando que, em sala de aula, ainda por cima, não falar corretamente era motivo de constrangimentos vários.

Desse livro constavam as seguintes orientações: "primeiro que tudo, o peito para frente e a cabeça direita. Nada de moleza: muita destreza antes. As mãos não devem estar nos bolsos, no dorso, nos cabelos, no ouvido e muito menos na boca" (Milano, 1914, p. 17). Um trecho como esse mostra a fisionomia mascarada da escolarização. Se podemos dizer que há uma liturgia na escola, que ela se estrutura por orquestrar um cerimonial de passagem, isso, contudo, não se faz sem ruídos. A simetria do ritual é sempre intercalada e, por vezes, rompida pela rebeldia. Há resistência entre os escolares. $\mathrm{E}$ quem é o aluno rebelde? Os alunos que dão trabalho são aqueles que estão sempre com as mãos nos bolsos, no ouvido ou na boca. Agitados, bamboleiam entre as pernas quando de pé, oscilando o próprio equilíbrio e o equilíbrio dos colegas que estão ao lado ou enfileirados. São aqueles que colocam os pés sobre a carteira, quando sentados. São aqueles avoados, que brincam com a caneta enquanto o professor explica a matéria, que não organizam seus livros. São os que não fazem a lição e nem sequer se importam com isso. São os que, ao sair da escola, andam em bandos, correndo travessos. São aqueles que, ao entrar na classe, fazem barulho, empurram as cadeiras. São irreverentes, ruidosos e atrevidos.

Enfim, são os que troçam do ritual da escola. São os que muito provavelmente não obtêm êxito nos exames e nas sabatinas. São os que não conseguem se familiarizar com a língua que a escola fala, com o rito orquestrado pelo que Justino Magalhães (2004) chamou de ecologia escolar. Nas escolas, sabemos isso todos, os sinais tocam. $E$ há inúmeros registros de sinais físicos e sinais simbólicos que tocam nas escolas e que tocam as escolas. O aluno repetente é aquele a quem, conforme observou Ana Laura Godinho Lima (1999; 2004), a escola não consegue ensinar a obedecer. O aluno repetente é, provavelmente, o aluno pobre, aquele que, por alguma razão, não se tornou cúmplice dos sinais que tocaram no rito escolar. Será, por isso, convencido pela escola que não passou de ano por ser rebelde. Será convencido, pela escola, que foi dela excluído por sua própria culpa (Patto, 1999, passim).

\section{A aula ritualizada por revistas do magistério}

Outro registro relevante para averiguar o lugar dos ritos escolares, como já evidenciaram António Nóvoa (1987), Denice Catani (1989), Maria Helena Camara Bastos (2005; 2011) e Jaime Cordeiro (1999; 2002), dentre outros, são as revistas pedagógicas. As revistas de ensino são poderosa fonte de informação sobre os saberes didáticos. Podem-se verificar, por elas, sugestões de construções de aulas feitas por professores, que, muitas vezes, escreviam nos periódicos. Os ritos aparecem descritos, mas também inscritos nas recomendações dadas aos professores acerca dos modos de controlar a conduta dos alunos.

A civilidade é um dos princípios estruturais do processo de socialização escolar. Mas a civilidade, no caso brasileiro e português, tem ainda a marca da fidalguia ou da distinção aristocrática. O discurso veiculado proclama a existência de hierarquias e degraus, com pessoas superiores e outras inferiores no tabuleiro social - cada uma devendo ser tratada de acordo com sua posição na hierarquia previamente estabelecida. Evidentemente, a 
distância entre adultos e crianças é uma das fronteiras que estabelece relações de subordinação e dependência. Essa vem explícita, ao passo que as demais - fronteiras de classe, de raça, de etnia, de gênero, de condição social - não são exatamente mencionadas. E a criança - acreditando na existência de natural subordinação entre homens, mulheres e crianças, entre poderosos e fracos, entre ricos e pobres - será preparada para a sociedade que a espera. Daí o caráter conservador da civilidade prescrita pela escolarização.

Roteiros de aula vinham minuciosamente expressos em revistas, cuja intenção era também, como evidenciou Ana Carolina Marangon (2011), a de oferecer aos mestres metodologias, ferramentas e instrumentos para ministrarem este ou aquele conteúdo. Os modos de ensinar, portanto, permaneciam e variavam em virtude das coisas a serem ensinadas. Cada um a seu tempo, todos teriam um ritual recomendado. Tratava-se apenas de encontrar a melhor forma de gerir a exposição e o exercício, ocupando de maneira mais hábil o espaço da classe e a temporalidade do horário.

Ao produzirem relatos na forma de aulas, tais articulistas estão, em alguma medida, indicando aos professores sobre como eles deveriam dar aulas. Contudo, pode-se considerar, por outro lado, que as aulas escritas para as revistas também são reportadas a aulas de verdade, a práticas existentes nas escolas, práticas provavelmente consideradas bem-sucedidas e, nessa condição, generalizáveis. Trata-se de criar, e as revistas pretendiam isso, roteiros de aula pensados como valiosos e apropriados para várias situações. A escola, pela revista, torna-se um sujeito genérico e passa a ser falada por seu coletivo, como uma representação de todo o universo passível de ser contido na categoria. A escola primária torna-se o lugar onde se aprende o escrito, mas onde, antes de qualquer coisa, se corrigem as falas, os linguajares e os sotaques regionais. Trata-se de ensinar a língua - a língua que unifica o país.

Na revista intitulada O Ensino: revista d'instrucção primaria - publicada em Lisboa, em dezembro de 1885, sob a direção de Theophilo Ferreira - havia uma seção intitulada Polymathia, que, neste número especificamente, trazia um exercício de correção de pronúncia como indicativo do "ensino de língua materna nas escolas primárias e elementares pelo método sintético analítico" (Reis, 1885, p. 202). Corrigir as falas significava compor pela escola uma clara diferenciação entre o repertório erudito expresso na cultura letrada e os hábitos vivenciados pelas comunidades regionais e familiares. Além de ensinar a ler e a escrever, compete à escola ensinar os alunos a falarem corretamente. Assinada por J. M. dos Reis, a referida coluna da sugeria claramente o movimento da aula:

Estes exercícios far-se-ão da maneira seguinte:

- Venha cá menino. Diga-me: como se chama?

- Jé.

- Não disse bem. Deve-se dizer: Juzé. Diga comigo: Ju-zé.

- Jujê.

- Ainda não disse bem. Não se diz Jê, mas sim Zé. Ora diga z...é

- Z...é.

- Diga mais depressa: Zé?

- Zé.

- Diga agora: ju...zé.

- Ju... Zé

- Disse bem. 
Esta mesma palavra se manda dizer a cada um dos outros alunos, demorando-se o professor com cada um o tempo necessário para que a pronúncia seja correta. $O$ aluno que a pronunciar bem da primeira vez passa para lugar superior ao dos outros. (Reis, 1885, p. 202)

O aprendizado da língua é também o aprendizado da escola e o aprendizado da escola é, certamente, o aprendizado da nação. Há que se lembrar que a língua comum é um dos primeiros elementos da mentalidade nacional. O moderno Estado nacional que, como sublinha Hobsbawm (2002), é firmado pela demarcação de fronteiras, pela organização de exércitos e pelo monopólio da justiça e dos impostos, precisará criar tradições, hábitos, memória e linguagem comum para se manter como tal. As fronteiras devem ser estruturadas, resguardadas características de comunhão e de alguma similitude. Os falares, os dizeres regionais precisarão ser, sob tal perspectiva, escrupulosamente controlados, de maneira a que não se excedam. Não se pode deixar a diferença cindir a comunhão necessária ao elemento nacional. Se o país é um território, ele é também uma língua e esta deve ser falada sem tropeços e sem muitas variações. $O$ aprendizado da língua é, por tudo isso, o primeiro aprendizado literal da pátria e da cidadania.

\section{Palavras finais}

Para concluir, discuto um pouco alguns caminhos que me parecem profícuos para trilhar o futuro da história da educação luso-brasileira. A meu ver, cabe, em alguma medida, retomar o entrelaçamento entre História e Filosofia da Educação, como um recurso conceitual para que se obtenham elementos passíveis de reconstituir a urdidura entre as práticas efetivamente engendradas nos diferentes rituais que diferentes escolas perfilham, em suas similaridades e em suas diferenças, e os traços do pensamento pedagógico que prescreve modos e maneiras de se dar aula, recomendando esta ou aquela por esta ou aquela razão.

Reconstituir a história das práticas de ensino, paralelamente à busca de compreensão das teorias pedagógicas, é uma maneira de se buscar apreender quais práticas foram as que mais deram certo, quais foram exitosas. Com isso teremos mais elementos para, porventura, compreender: por que esta ou aquela escola, este ou aquele professor ensinam bem ou ensinam mal? Quais são as formas de ensinar mais merecedoras de crédito por seus méritos, por seus resultados e por seu reconhecimento público? Quais são os ritos que precisarão ser abolidos do cenário da sala de aula?

Ao buscar no passado aspectos capazes de interagir com problemas de nosso tempo presente - como historiadores - poderemos retomar a fertilidade de uma história do pensamento educacional que não seja cindida do estudo das condições materiais do ensino de sua época. Não se trata de elaborar o que já foi denunciado como sínteses desencarnadas, mas pensar algumas das intersecções entre o pensamento pedagógico e as realidades concretas das escolas constitui num desafio colocado para as novas gerações. De fato, se a escola inventa seus modos de ser e de agir, se os ritos ali produzidos são cerimônias e protocolos internos, pode-se, mesmo assim, considerar que essa invenção tem a baliza de algumas referências. Referências teóricas, conceituais e referências de métodos. 
Como pensar os estilos pelos quais se processou o ensino nas diferentes tradições nacionais, regionais, locais, em um mundo em constante deslocamento? As novas tecnologias da informação, bem como as modificações no cenário migratório e demográfico acarretam inusitadas problemáticas para projetarmos os temas da História da Educação. O processo de mundialização da economia trará consigo a pretensão de uniformizar práticas e reinstalar rituais? Como articular a tradição da escola moderna com as novas demandas da sociedade digital se todo o formato da escola ainda é tributário da cultura do livro impresso?

A História da Educação ainda é território privilegiado para tomar do passado as pistas que podem nos conduzir à iluminação do presente. Trata-se, sob qualquer hipótese, de investigar, sistematizar e divulgar os movimentos e os deslocamentos pelos quais ritos e tradições escolares são constituídos: por saberes, por valores, por atitudes e por exemplos.

\section{Referências}

A ESCOLA publicação semana para creanças. São Manoel do Paraizo. 14 de fevereiro de 1904. Anno I, n. 1. p. 5-6.

ADÃO, Áurea. Estado absoluto e ensino das primeiras letras: as escolas régias (17591794). Lisboa: Calouste Gulbenkian, 1997.

AFFREIXO, José Maria da Graça; FREIRE, Henrique. Elementos de pedagogia para servirem de guia aos condidatos ao magistério primário. Lisboa: Livraria Ferreira, 1879.

AGULHON, Maurice. 1848: o aprendizado da república. Rio de Janeiro: Paz e Terra, 1991.

ALMEIDA, Vanessa Sievers. A distinção entre conhecer e pensar em Hannah Arendt e sua relevância para a educação. Educação e Pesquisa, v. 36, n. 3, 2010, p. 953-865.

ALVES, Eva Maria Siqueira. O Atheneu Sergipense: uma saga de educação literária examinada segundo os Planos de Estudos (1870-1908). São Paulo: PUCSP, 2005. 318p. Tese (doutorado em Educação). Programa de Estudos Pós-Graduados em Educação, Pontifícia Universidade Católica de São Paulo.

AMÂNCIO, Lázara Nanci de Barros. Ensino de leitura e grupos escolares. Cuiabá: UFMT, 2008.

ANAQUIM, Conego Manuel. Compendio de moral e doutrina christã. Lisboa: Livraria Ferreira, 1906.

ANJO, César. Crianças tímidas e apáticas. Revista Escolar, ano 3, n. 3, 1923, p. 92-3.

AQUINO, Julio Groppa. A escrita como modo de vida: conexões e desdobramentos educacionais. Educação e Pesquisa, v. 37, n. 3, 2011, p. 641-656.

ARENDT, Hannah. Entre o passado e o futuro. São Paulo: Perspectiva, 1979.

ARISTÓTELES. Ética a nicômacos. Brasília: UNB, 2001.

AZANHA, José Mário Pires. Cultura escolar brasileira: um programa de pesquisas. Revista USP, n. 8 , 1990-91, p. 65-69.

AZANHA, José Mário Pires. Educação: alguns escritos. São Paulo: Editora Nacional, 1987.

AZANHA, José Mário Pires. Uma idéia de pesquisa educacional. São Paulo: USP, 1992. 
BASTOS, António. Grammática intuitiva da língua portuguesa. Porto: Livraria Editora de Antonio Figueirinhas, 1901.

BASTOS, Maria Helena Camara. A Revista do Ensino/RS: o novo e o nacional em revista. Pelotas: Seiva, 2005.

BASTOS, Maria Helena Camara. Manuais escolares franceses no Imperial Colégio Pedro II (1856-1892). Hist. Educ. (Online), v. 2, 2008, p. 39-58.

BASTOS, Maria Helena Camara. Peço a palavra: a politesse dos rituais. Cadernos de Pesquisa, v. 3, 2008, p. 135-146.

BASTOS, Maria Helena Camara. Pedagogias e manuais: leituras cruzadas - os manuais de história da educação adotados no Brasil (1870-1950). BESTANI, Rosa M; BRUNETTI, Paulina; SÁNCHEZ, Ana M. Martinez; FLACHS, Maria Cristina Vera de (orgs.). Textos, autores y bibliotecas: 190 años de la Biblioteca Mayor de la UNC. Córdoba: Baez, 2011, p. 493-511.

BASTOS, Maria Helena Camara. Aprendendo o labor docente: o Curso Prático de Pedagogia, de Jean-Baptiste Daligault (1851). In: PERANDONES, Pablo Celada (ed.). Arte y oficio de enseñar: XVI Coloquio Nacional de Historia de la Educación. El Burgo de Osma: Universidade de Valladolid/Sociedade Española de Historia de la Educación, 2011. p. 497-505.

BENCOSTTA, Marcos Levy. A. (org.). História da educação, arquitetura e espaço escolar. São Paulo: Cortez, 2005.

BENCOSTTA, Marcus Levy Albino. A cultura escolar na historiografia da educação brasileira: alcances e limites de um conceito. In: FELGUEIRAS, Margarida Louro; VIEIRA, Carlos Eduardo (org.). Cultura escolar, migrações e cidadania. Porto: Sociedade Portuguesa de Ciências da Educação, 2010, p. 33-46.

BITTENCOURT, Circe Maria Fernandes. Livro didático e conhecimento histórico: uma história do saber escolar. São Paulo: USP, 1993. 384p. Tese (doutorado em Educação). Faculdade de Filosofia, Letras e Ciências Humanas, Universidade de São Paulo.

BITTENCOURT, Feliciano Pinheiro. Compendio de pedagogia escolar. Rio de Janeiro: Livraria Francisco Alves, 1908.

BLOCH, Marc. Apologia da história ou o ofício do historiador. Rio de Janeiro: Jorge Zahar, 2001.

BOMFIM, M. Lições de pedagogia: theoria e pratica da educação. Rio de Janeiro: Fancisco Alves, 1920.

BORNE, Dominique. Comunidade de memória e rigor crítico. In: BOUTIER, Jean; JULIA, Dominique. Passados recompostos: campos e canteiros da história. Rio de Janeiro: UFRJ/FGV, 1998, p. 133-141.

BOTO, Carlota Josefina Malta Cardozo dos Reis. Ler, escrever, contar e se comportar: a escola primária como rito do século 19 português (1820-1910). São Paulo: USP, 1997. 606p. Tese (doutorado em Educação). Faculdade de Filosofia, Letras e Ciências Humanas, Universidade de São Paulo.

BOTO, Carlota. A civilização escolar nas letras de um roteiro de pedagogia: formação impressa de professores. CONGRESSO DE LEITURA DO BRASIL, 16, 2007. Anais ... Campinas: ABL, 2007.

BOTO, Carlota. Compêndios pedagógicos de Augusto Coelho (1850-1925): a arte de tornar ciência o ofício de ensinar. Hist. Educ. (Online), v. 14, n. 30, 2010, p. 9-60. 
BOTTERO, Jean et al. Cultura, pensamento e escrita. São Paulo: Ática, 1995.

BUFFA, Esther. Os estudos sobre instituições escolares: organização do espaço e propostas pedagógicas. In: NASCIMENTO, Maria Isabel M; SANDANO, Wilson; LOMBARDI, José C; SAVIANI, Dermeval (org.). Instituições escolares no Brasil: conceito e reconstrução histórica. Campinas: Autores Associados, 2007, p. 151-164.

BURKE, Peter. A arte da conversação. São Paulo: Unesp, 1995.

BURKE, Peter. O que é história cultural? Rio de Janeiro: Zahar, 2005.

CAMBI, Franco. História da pedagogia. São Paulo: Unesp, 1999.

CAMPS, Victoria. Civismo. España: Proteus, 2011.

CÂNDIDO, Antônio. A estrutura da escola. In: PEREIRA, Luiz; FORACCHI, Marialice M. Educação e sociedade. São Paulo: Companhia Editora Nacional, 1977, p. 107-128.

CARVAlHO, Felisberto de. Primeiro livro de leitura. Rio de Janeiro: Francisco Alves, 1926.

CARVALHO, José Sérgio Fonseca. A liberdade educa ou a educação liberta? Uma crítica das pedagogias da autonomia à luz do pensamento de Hannah Arendt. Educação e Pesquisa, v. 36, n. 3, 2010, p. 940-851.

CARVALHO, Marta M. Chagas. Livros e revistas para professores: configuração material do impresso e circulação internacional de modelos pedagógicos. In: PINTASSILGO, Joaquim; CARVALHO, Marta Maria Chagas de; FREITAS, Marcos Cezar. C; MOGARRO, Maria João. História da escola em Portugal e no Brasil: circulação e apropriação de modelos culturais. Lisboa: Colibri, 2006, p. 141-173.

CARVALHO, Marta Maria Chagas de. A escola e a república. São Paulo: Brasiliense, 1989.

CARVALHO, Marta Maria Chagas de. Molde nacional e fôrma cívica: higiene, moral e trabalho no projeto da Associação Brasileira de Educação (1924-1931). Bragança Paulista: USF, 1998.

CARVALHO, Marta Maria Chagas. A caixa de utensílios e a biblioteca: pedagogia e práticas de leitura. In: VIDAL, Diana Gonçalves; HILSDORF, Maria Lúcia Spedo (org.). Brasil 500 anos: tópicas de história da educação. São Paulo: Edusp, 2001, p. 137-167.

CASTILHO, Antonio Feliciano. Felicidade pela instrucção: cartas a um jornal de Lisboa. Lisboa: Empreza da História de Portugal, 1909.

CASTRO, Cesar A. Infância e trabalho no Maranhão provincial: uma história da Casa dos Educandos Artífices. São Luís: Func, 2007.

CATANI, Denice Barbara. Educadores à meia-luz: um estudo sobre a Revista de Ensino da Associação Beneficente do Professorado Público de São Paulo 1902-1919. São Paulo: USP, 1989. Tese (doutorado em Educação). Faculdade de Educação, Universidade de São Paulo.

CATANI, Denice. Educadores à meia-luz: um estudo sobre a Revista do Ensino da Associação Beneficiente do Professorado Público de São Paulo. Bragança Paulista: Edusf, 2003.

CATROGA, Fernando. Nação, mito e rito: religião civil e comemoracionismo. Fortaleza: UFC/Museu do Ceará/Secretaria da Cultura do Ceará, 2005.

CATROGA, Fernando. O republicanismo em Portugal: da formação ao 5 de outubro de 1910. Coimbra: Faculdade de Letras, 1991. 
CATROGA, Fernando. Os passos do homem como restolho do tempo: memória e fim do fim da História. Coimbra: Almedina, 2009.

CAVALCANTE, Maria Juraci Maia (org.). História e memória da educação no Ceará. Fortaleza: UFC, 2002

CAVALCANTI, Maria Juraci Maia et al. História da educação: vitrais da memória - lugares, imagens e práticas culturais. Fortaleza: UFC, 2008.

CHARTIER, Anne-Marie. Escola, culturas e saberes. In: XAVIER, Libâneia Nacif; CARVALHO, Marta Maria Chagas; MENDONÇA, Ana Waleska; CUNHA, Jorge Luiz. Escola culturas e saberes. Rio de Janeiro: FGV, 2005, p. 9-28.

CHARTIER, Anne-Marie. Fazeres ordinários da classe: uma aposta para a pesquisa e para a formação. Educação e Pesquisa. São Paulo. v. 26, n. 2. 2000, p. 157-168.

CHARTIER, Anne-Marie; HÉBRARD, Jean. Discours sur la lecture (1880-1980). Paris: Centre George-Pompidou, 1989.

CHARTIER, Roger. A história cultural: entre práticas e representações. Lisboa: Difel, 1990.

CHARTIER, Roger. Cultura escrita, literatura e história. Porto Alegre: Artmed, 2001.

CHARTIER, Roger. Lectures et lecteurs dans la France d'ancien regime. Paris: Seuil, 1987.

CHERVEL, André. La culture scolaire: une approche historique. Paris: Belin, 1998.

CHEVALLARD, Yves. La transposition didactique. Paris: La Pensée Sauvage, 1991.

CODIGO de Instrucção Publica da Província de São Paulo: organisado pela commissão composta dos Snrs. Dr. Antonio Joaquim Ribas, Dr. João Dabney de Avellar Brotero e Diogo de Mendonça Pinto. Nomeada pelo governo em virtude da Lei Provincial n. 30 de 10 de maio de 1854. Artigo 30. São Paulo: Typographia Dous de Dezembro de Antonio Louzada Antunes, 1857.

COELHO, J. Augusto. Noções de pedagogia elementar. Lisboa: Empreza da História de Portugal, 1907.

COMENIUS. Didática magna. São Paulo: Martins Fontes, 1997.

CORDEIRO, Jaime Francisco Parreira. Falas do novo, figuras da tradição: o novo e o tradicional na educação brasileira (anos 70 e 80). São Paulo: Unesp, 2002.

CORDEIRO, Jaime Francisco Parreira. Projetando a mudança: o novo e o tradicional na educação brasileira (anos 70 e 80). São Paulo: USP, 1999. 248f. Tese (doutorado em Educação). Faculdade de Educação, Universidade de São Paulo.

CORREIA, Adriano. Natalidade e amor mundi: sobre a relação entre educação e política em Hannah Arendt. Educação e Pesquisa. São Paulo, v. 36, n. 3, 2010, p. 911-822.

CORREIA, Velhinho. O ensino e a educação em Portugal. Lisboa: Livraria Clássica, 1907.

CUNHA, Maria Teresa Santos. A escola, os livros e a leitura: à procura daquilo que não se fez esquecer. In: FISCHER, Beatriz T. Daudt (org.). Tempos de escola: memórias. São Leopoldo: Oikos, 2011, p. 121-132.

CUNHA, Maria Teresa Santos. Mensageiro de sociabilidades: estudos sobre um jornal escolar infantil (1946-1952). In: MORGA, Antonio Emílio (org.). História, cidade e sociabilidades. Itajaí: Casa Aberta, 2011, p. 235-250. 
CUNHA, Maria Teresa Santos. Ser de cerimônia: manuais de civilidade e a construção de suieitos históricos (1920-1960). In: NEPONUCEMO, Maria de Araújo; TIBALLI, Elianda Figueiredo Arantes (orgs.). A educação e seus sujeitos na história. Belo Horizonte: Argvmentvm, 2007, p. 91-107.

DAMIÃO, Dalila Rodrigues. Cartilhas escolares e livros de primeiras leituras no Brasil do século 19 e 20. São Paulo: Monografia de Iniciação Científica, 2006. Faculdade de Educação, Universidade de São Paulo.

DICCIONARIO da lingua portugueza recopilado dos vocabulários impressos até agora, e nesta segunda edição novamente emendado, e muito accrescentado, por Antonio de Moraes Silva, natural do Rio de Janeiro, offerecido ao muito alto, e muito poderoso Principe Regente N. Senhor. Tomo Primeiro. Lisboa: Na Typographia Lacerdina, 1813.

DUBAR, Claude. A crise das identidades: a interpretação de uma mutação. São Paulo: Edusp, 2009.

DUBET, François. L'école dês chances: qu'est-ce qu'une école juste? Paris: Éditions du Seuil, 2004.

DURKHEIM, É. A educação como processo socializador: função homogeneizadora e função diferenciadora. In: PEREIRA, Luiz; FORACCHI, Marialice M. Educação e sociedade. São Paulo: Companhia Editora Nacional, 1977, p. 34-48.

EAGLETON, Terry. A ideia de cultura. São Paulo: Unesp, 2005.

EDUCAÇÃO Nacional: supplemento - discussões pedagógicas e exercícios práticos. Domingo 1 de outubro de 1899, n. 1.

EDUCAÇÃO Nacional: supplemento - discussões pedagógicas e exercícios práticos. Domingo 3 de junho de 1900, n. 9.

EISENSTEIN, Elizabeth L. A revolução da cultura impressa: os primórdios da Europa moderna. São Paulo: Ática, 1998.

ELIADE, Mircea. O mito do eterno retorno. Lisboa: Edições 70, 1984.

ELIAS, Norbert. A sociedade de corte. Lisboa: Editorial Estampa, 1987.

ELIAS, Norbert. La dynamique de l'occident. Paris: Calmann-Lvy, 1975.

ELIAS, Norbert. O processo civilizador. volume 1. Rio de Janeiro: Zahar, 1994.

ELIAS, Norbert. O processo civilizador. volume 2. Rio de Janeiro: Zahar, 1993.

FARIA FILHO, Luciano; VIDAL, Diana Gonçalves. Os tempos e os espaços escolares no processo de institucionalização da escola primária no Brasil. Revista Brasileira de Educação, n. 14, 2000.

FARIA FILHO, Luciano Mendes. Dos pardieiros aos palácios: forma e cultura escolares em Belo Horizonte (1906-1918). São Paulo: USP, 1996. 363f. Tese (doutorado em Educação). Faculdade de Educação, da Universidade de São Paulo.

FEITOSA, Miguel Alves. Duas palavras sobre o ensino. São Paulo: Typ. de Vanorden \& Cia., 1892.

FELGUEIRAS, Margarida Louro. Cultura escolar: da migração do conceito à sua objetivação histórica. In: FELGUEIRAS, Margarida Louro; VIEIRA, Carlos Eduardo (org.). Cultura escolar, migrações e cidadania. Porto: Sociedade Portuguesa de Ciências da Educação, 2010, p. 17-32.

FERNANDES, Rogério. Os caminhos do $A B C$ : sociedade portuguesa e ensino das primeiras letras. Porto: Porto, 1994. 
FERREIRA, António Gomes Alves. A criança no Portugal de setecentos: contributo para o estudo da evolução dos cuidados e das atitudes para com a infância. Coimbra: Universidade de Coimbra, 1996. Tese (doutorado em Educação). Universidade de Coimbra.

FONSECA, Thais Nivia Lima e. Instrução e assistência na Capitania de Minas Gerais: das ações das câmaras às escolas para meninos pobres (1750-1814). Revista Brasileira de Educação, v. 13, 2008, p. 535-544.

FORACCHI, Marialice M. Educação e sociedade. São Paulo: Companhia Editora Nacional, 1977.

FORQUIN, Jean-Claude. Escola e cultura: as bases sociais e epistemológicas do conhecimento escolar. Porto Alegre: Artes Médicas, 1993.

FOUCAULT, Michel. Vigiar e punir. São Paulo: Vozes, 2003.

FRAGO, Antonio Viñao; ESCOLANO, Agustin. Currículo, espaço e subjetividade: a arquitetura como programa. Rio de Janeiro: DP\&A, 1998.

FRANCO, Maria Sylvia de Carvalho. Homens livres na ordem escravocrata. São Paulo: Kairós, 1983.

FURET, François; OZOUF, Jacques. Lire et écrire: l'alphabétisation des Français de Calvin à Jules Ferry. Paris: Les Editions de Minuit, 1977.

GALHARDO, Thomas. Terceiro livro de leitura. 19 ed. Rio de Janeiro: Francisco Alves, 1919.

GALLEGO, Rita de Cássia. A configuração temporal e as inovações nos modos de ensinar e aprender nas escolas públicas primárias (São Paulo- Brasil 1850 a 1890). In: PERANDONES, Pablo Celada (ed.). Arte y oficio de enseñar. El Burgo de Osma, Espanha: Sociedad Española de Historia de la Educación/Universidad de Valladolid, 2011, p. 1-10.

GALLEGO, Rita de Cassia. A configuração temporal e as inovações nos modos de ensinar e aprender nas escolas públicas primárias (São Paulo - Brasil - 1850 a 1890). In: PERANDONES, Pablo Celada (ed.) Arte y oficio de enseñar. El Burgo de Osma: Sociedad Española de Historia de la Educación / Universidad de Valladolid/ Centro Internacional de la cultura escolar, 2011, p. 117-125.

GALVÃO, Ana Maria de Oliveira. A palmatória era a sua vara de condão: práticas escolares na Paraíba (1890-1920). In: FARIA FILHO, Luciano Mendes (org.). Modos de ler/formas de escrever: estudos de história da leitura e da escrita no Brasil. Belo Horizonte: Autêntica, 1998, p. 117-142.

GÉLIS, Jacques. A individualização da criança. In: ARIĖS, Philippe; DUBY, Georges. História da vida privada: da renascença ao século das luzes. São Paulo: Companhia das Letras, 1991, p. 311-329.

GONDRA, José Gonçalves. Artes de civilizar: medicina, higiene e educação escolar na Corte imperial. Rio de Janeiro: Eduerj, 2004.

GRAFF, Harvey. Os labirintos da alfabetização: reflexões sobre o passado e o presente da alfabetização. Porto Alegre: Artes Médicas, 1994.

HAMILTON, David. Notes from nowhere (on the beginning of modern schooling). In: POPKEWITZ, Thomas S; PEREYRA, Miguel A; FRANKLIN, Barry M. POPKEWITZ, Thomas S; PEREYRA, Miguel A; FRANKLIN, Barry M. Cultural history and education. New York: Routlegdefalmer, 2001, p. 187-206. 
HÉBRARD, Jean. Por uma bibliografia material das escritas ordinárias: o espaço gráfico do caderno escolar (França - Séculos 19 e 20). Revista Brasileira de História da educação, n. 1, 2001.

HILSDORF, Maria Lucia Spedo. Educação e instrução na província de São Paulo. In: GONDRA, José Gonçalves (org.). Educação e instrução nas províncias e na corte imperial. Brasil, 1822-1889. Vitória: UFES/SBHE, 2011, p. 337-373.

HILSDORF, Maria Lucia Spedo. Tempos de escola: fontes para a presença feminina na educação escolar, São Paulo, século 19. In: GONDRA, José Gonçalves (org.). Dos arquivos à escrita da história: a educação brasileira entre o Império e a República no século 19. Bragança Paulista: USF, 2002, p. 133-145.

HILSDORF, Maria Lucia Spedo. Pensando a educação nos tempos modernos. São Paulo: USP, 1998.

HOBSBAWM, Eric J. Nações e nacionalismo desde 1780. Rio de Janeiro: Paz e Terra, 2002.

INSPECTORIA GERAL DA INSTRUCÇÃO PUBLICA. [ofício manuscrito n. 79. De Diogo de Mendonça Pinto dirigido ao Conselheiro José Joaquim Fernandes Torres, Presidente da Província de São Paulo, em 28 de janeiro de 1858. http://www.arquivoestado. sp.gov.br/educacao/destaque

JOÃO DE DEUS. Cartilha maternal ou arte da leitura. $3^{\mathrm{a} e d .}$ Lisboa: Imprensa Nacional, 1878.

JOHNSON, Allan G. Dicionário de sociologia. São Paulo: Zahar, 1997.

JULIA, Dominique. A cultura escolar como objeto histórico. Revista Brasileira de História da Educação, n. 1. 2001, p. 9-43.

KANT, Immanuel. Fundamentação da metafísica dos costumes. Lisboa: Edições 70, 1988.

KUHLMANN, Moysés. Histórias da educação infantil brasileira. Revista Brasileira de Educação, n. 14, 2000, p. 5-18.

KULESZA, Wojciech Andrzej. Desarrollo de los manuales pedagógicos em Brasil (18701940). In: PERANDONES, Pablo Celada (ed.). Arte y oficio de enseñar: XVI Coloquio Nacional de Historia de la Educación. El Burgo de Osma: Universidade de Valladolid/Sociedade Española de Historia de la Educación, 2011. p. 557-566.

LEAL, Victor Nunes. Coronelismo, enxada e voto. São Paulo: Alfa-ômega, 1975.

LEITÃO, António. Elementos de pedagogia em harmonia com os programas das escolas normais. Coimbra: França e Armenio Livreiros-Editores, 1916.

LEITURA MANUSCRIPTA: lições colligidas por B.P.R. aprovada para ser adotada em todas as escolas publicas do Estado. Exemplar pertencente à Biblioteca da Escola Normal de São Paulo / Coleção Paulo Borroul. s/d.

LIMA, Ana Laura Godinho. De como ensinar o aluno a obedecer: um estudo dos discursos sobre disciplina escolar entre 1944 e 1965. São Paulo: USP, 1999. Dissertação (mestrado em Educação). Faculdade de Educação, Universidade de São Paulo.

LIMA, Ana Laura Godinho. O espectro da irregularidade ronda o aluno: um estudo da literatura pedagógica e da legislação sobre a criança-problema. São Paulo: USP, 2004. 236f. Tese (doutorado em Educação). Faculdade de Educação, Universidade de São Paulo.

LOPES, Eliane Marta Teixeira; FARIA FILHO, Luciano Mendes; VEIGA, Cynthia Greive. 500 anos de educação no Brasil. Belo Horizonte: Autêntica, 2000. 
LOPES, José Quintino Travassos. Leituras correntes e intuitivas. Lisboa: Typographia e Stereotypia Moderna, 1897.

MACHADO, Ulysses. Livro de leitura para a segunda classe do ensino primário geral. Lisboa: Livraria Rodrigues, 1922.

MADEIRA, Maria das Graças de Loyola. A pedagogia feminina das casas de caridade do padre Ibiapina. Fortaleza: UFC, 2008.

MADEIRA, Maria das Graças Loiola. Entre orações, letras e agulhas: a pedagogia feminina das Casas de Caridade do Padre Ibiapina - Sertão Cearense (1855-1883). Fortaleza: UFCE, 2003. 240f. Tese (doutorado em Educação). Faculdade de Educação, Universidade Federal do Ceará.

MAGALHÃES, Justino. Tecendo nexos: história das instituições educativas. São Paulo: Universidade São Francisco, 2004.

MAGNOLI, Demétrio. O corpo da pátria: imaginação geográfica e política externa no Brasil (1808-1912). São Paulo: Unesp/Moderna, 1997.

MANNHEIM, Karl; STEWART, William Alexander Campbell. O subgrupo de ensino. PEREIRA, Luiz; FORACCHI, Marialice M. Educação e sociedade: leituras de sociologia da educação. São Paulo: Companhia Editora Nacional, 1977, p. 129-137.

MARANGON, Ana Carolina Rodrigues. Crianças e alunos em sala de aula: a circulação do debate sobre métodos de ensino em Portugal e no Brasil (1930-1940). São Paulo: USP, 2011. 371f. Tese (doutorado em Educação). Faculdade de Educação, Universidade de São Paulo.

MARINS, Maria Carolina. Provas escriptas da alumna do $4^{\circ}$ anno do Grupo Escolar Antonio Padilha, em Sorocaba, Maria Carolina Marins, em 3 de dezembro de 1896. Historia do Brasil - Thomé de Souza. Manuscrito do Arquivo do Estado de São Paulo. Disponível em www.arquivoestado.sp.gov.br/pageflip/prophp/main.php?MaglD=1069\& MagNo-1069.

MATHIESON, Louisa Campbell. Conversas sobre ler e escrever: alfabetização e cultura escolar na Revista de Ensino (1902-1910). São Paulo: USP, 2009. 77f. Monografia (trabalho complementar de curso). Faculdade de Educação, Universidade de São Paulo.

MCLAREN, Peter. Rituais na escola: em direção a uma economia política de símbolos e gestos na educação. Petrópolis: Vozes, 1992.

MENDONÇA, Ana Waleska Pollo; CARDOSO, Tereza Maria Fachada Levy. A gênese de uma profissão fragmentada. Revista Brasileira de História da Educação, n. 15, 2007, p. 30-49.

MENEZES, Antonio Guedes de Carvalho. Quesitos a que os inspectores devem responder com relação às escolas primarias não mantidas pelo estado. Manuscrito localizado no Arquivo Nacional da Torre do Tombo/ Secretaria de Estado da Cultura/ Presidência do Conselho de Ministros. 12 de maio de 1875.

MILANO, Miguel. Para bem ler e bem recitar: methodo ortophonico. São Paulo: Typographia do Globo, 1914.

MOGARRO, Maria João. A formação de professores no Portugal contemporâneo: a escola do magistério primário de Portalegre. Tese (doutorado em Educação). Extremadura: Universidade da Extremadura, 2001.

MONARCHA, Carlos. Escola normal da praça: o lado noturno das luzes. Campinas: Unicamp, 1999. 
MONTEVERDE, Emílio Achilles. Methodo facillimo para aprender a ler tanto a letra redonda como a manuscrita no mais curto espaço de tempo. 7 ed. Lisboa: Imprensa Nacional, 1859.

MORAES, Carmen Sylvia Vidigal. O ideário republicano e a educação: uma contribuição à história das instituições. Campinas: Mercado das Letras, 2006.

MORTATTI, Maria do Rosário Longo. Os sentidos da alfabetização (1876/1994). São Paulo: Unesp, 2000.

MOSCOVICl, Serge. La psicanalyse, son image et son public. Paris: Presses Universitaires de France, 1961.

MOTTA, Diomar G. Uma instituição feminina na modernidade do século XVII no Maranhão. Educação e Emancipação, v. 3, 2004, p. 51-62.

MR 1072. Quesitos aos inspectores das escolas primarias mantidas pelo Estado. Districto: Évora. Concelho: Estremoz. Freguezia: Santo André. Escola Primaria para o Sexo Masculino com Sede na Villa d'Estremoz. Imprensa Nacional, 1874. Manuscrito localizado no Arquivo Nacional da Torre do Tombo/ Secretaria de Estado da Cultura/ Presidência do Conselho de Ministros.

MUNAKATA, Kazumi. Livro didático: produção e leituras. In: ABREU, Márcia (org.). Leitura, história e história da leitura. Campinas: Mercado de Letras, Associação de Leitura do Brasil, Fapesp, 1999, p. 577-610.

NAGLE, Jorge. Discurso pedagógico: uma introdução. In: NAGLE, Jorge. Educação e linguagem. São Paulo: Edart, 1976, p. 11-42.

NASCIMENTO, Ester Fraga Vilas-Bôas Carvalho do. Práticas educacionais protestantes no século 19: o caso de Sergipe. Universidade e Sociedade, Brasília, n. 27, 2002, p. 100107.

NEIRHOT, Patrick. No princípio era o direito. In: BOUTIER, Jean; JULIA, Dominique. Passados recompostos: campos e canteiros da História. Rio de Janeiro: UFRJ/FGV, 1998, p. 91-103.

NOGUEIRA, Marco Aurélio. O encontro de Joaquim Nabuco com a política: as desventuras do liberalismo. São Paulo: Paz e Terra, 2010.

NORONHA, José Feliciano de Castilho Barreto. Iris clássico coordenado e oferecido aos mestres e aos alunos das escolas brasileiras por. 6 ed. Rio de Janeiro: Eduardo \& Henrique Laemmert, 1873.

NÓVOA, António Manuel Sampaio da. História da educação. Faculdade de Psicologia e Ciências da Educação/Universidade de Lisboa: [mimeografado], 1994.

NÓVOA, António. Histoire \& comparaison. Lisboa: Educa, 1998.

NÓVOA, António. Le temps des professeurs. Lisboa: Imprensa Nacional, 1987.

NÓVOA, António. Para o estudo sócio-histórico da gênese e desenvolvimento da profissão docente. In: Teoria e Educação, n. 4, 1991.

NÓVOA, António. Profissão professor. Porto: Porto, 1995.

NÓVOA, António. Texts, images and memories: writing new histories of education. In: POPKEWITZ, Thomas S; PEREYRA, Miguel A; FRANKLIN, Barry M. POPKEWITZ, Thomas S; PEREYRA, Miguel A; FRANKLIN, Barry M. Cultural history and education. New York: Routlegdefalmer, 2001, p. 45-66. 
O MÉTODO pedagógico dos jesuítas. In: FRANCA, Padre Leonel. Obras completas - X. Rio de Janeiro: Agir, 1952, p. 119-230.

DO Ó, Jorge Ramos. O governo de si mesmo: modernidade pedagógica e encenações disciplinares do aluno liceal. Lisboa: Educa, 2003.

ODÁLIA, Nilo. As formas do mesmo: ensaios sobre o pensamento historiográfico de Varnhagen e Oliveira Vianna. São Paulo: Unesp, 1997.

OLSON, David R. O mundo no papel: as implicações conceituais e cognitivas da leitura e da escrita. São Paulo: Ática, 1997.

ONG, Walter. Oralidade e cultura escrita. Campinas: Papirus, 1998.

PARO, Vitor Henrique. O currículo do ensino fundamental como tema de política pública: a cultura como conteúdo central. Ensaio: avaliação e políticas públicas em educação. Rio de Janeiro, n. 72 , v. 19,2011 , p. 485-507.

PASSALAQUA, Camilo. Pedagogia e methodologia (theorica e prática). São Paulo: Typographia a Vapor de Jorge Seckler \& Companhia, 1887.

PATTO, Maria Helena Souza. A produção do fracasso escolar: histórias de submissão e rebeldia. São Paulo: Casa do Psicólogo, 1999.

PETITAT, André. Produção de escola/produção de sociedade. Porto Alegre: Artes Médicas, 1994.

PINTASSILGO, Joaquim. Em torno da arte de ensinar: vocação, paixão, exemplaridade moral e prática. In: PERANDONES, Pablo Celada (ed.). Arte y oficio de enseñar: XVI Coloquio Nacional de Historia de la Educación. El Burgo de Osma: Universidade de Valladolid/Sociedade Española de Historia de la Educación, 2011, p. 201-208.

PINTASSILGO, Joaquim. Imagens e leituras da educação nova em Portugal: os relatórios de bolseiros portugueses em visita a instituições educativas europeias (1907-1909). In: MIGNOT, Ana Cristina; GONDRA, José Gonçalves (orgs.). Viagens pedagógicas. São Paulo: Cortez, 2007, p. 195-216.

PINTASSILGO, Joaquim. República e formação de cidadãos: a educação cívica nas escolas primárias da primeira república portuguesa. Lisboa: Colibri, 1998.

POPKEWITZ, Thomas S. The production of reason and power: curriculum history and intellectual traditions. In: POPKEWITZ, Thomas S; PEREYRA, Miguel A; FRANKLIN, Barry ; POPKEWITZ, Thomas S; PEREYRA, Miguel A; FRANKLIN, Barry M. Cultural history and education. New York: Routlegdefalmer, 2001b, p. 151.183.

POPKEWITZ, Thomas S; PEREYRA, Miguel A; FRANKLIN, Barry M. History, the problem of knowledge and the new cultural history of schooling. In: POPKEWITZ, Thomas S; PEREYRA, Miguel A; FRANKLIN, Barry M. POPKEWITZ, Thomas S; PEREYRA, Miguel A; FRANKLIN, Barry M. Cultural history and education. New York: Routlegdefalmer, 2001a, p. 3-42.

POSTMAN, Neil. O desaparecimento da infância. Rio de Janeiro: Graphia, 1999.

PRAIRAT, Eirick. Eduquer e punir. Nancy: Presses Universitaires de Nancy, 1994.

PRINCIPIOS gerais do methodo do ensino mutuo chamado de Lancaster para instrução das pessoas que se dedicão ao conhecimento d'este ensino. Nova edição. Lisboa: Impressão de Elias José da Costa Sanches, 1837.

RELATORIO de Instruç̧ão Publica da Província de São Paulo: em 1857 apresentado ao $\mathrm{Exm}^{\circ}$. Presidente da Provincia por Diogo de Mendonça Pinto, bacharel formado em Sciencias Juridicas e Sociaes, professor de Historia e Geographia da Faculdade de 
Direito d'esta cidade e Inspector Geral da Instrucção Publica. São Paulo: Typographia Dous de Dezembro, 1858.

RELATORIO do Estado da Instrucção Publica da Província de São Paulo em 1854: apresentado ao $\mathrm{Exm}^{\circ}$. Presidente da Provincia pelo bacharel formado Diogo de Mendonça Pinto, Inspector Geral da Instrucção Publica. São Paulo: Typographia 2 de Dezembro, 1855.

RELATORIO do Estado da Instrucção Publica da Provincial no anno de 1852: apresentado ao Exm . Presidente da Provincia pelo Inspector Geral da Instrucção Publica, o bacharel formado Diogo de Mendonça Pinto, São Paulo: Typographia 2 de Dezembro, s/d.

RELATORIO do Estado da Instrucção Publica da Provincial. Inspectoria Geral da Instrucção Publica de São Paulo. Diogo de Mendonça Pinto. 26 de dezembro de 1861.

RELATORIOS de Instrucção Publica da Província de São Paulo: nos annos de 1862 e 1863 apresentados ao Exm ${ }^{\circ}$. Governodor da Provincia pelo Inspector Geral da Instrucção Publica Diogo de Mendonça. São Paulo: Typographia Imparcial de J. R. A. Marques, 1864.

REVEL, Jacques. Os usos da civilidade. ARIÈS, P. DUBY, G. História da vida privada: da renascença ao século das luzes. São Paulo: Companhia das Letras, 1991, p. 169-209.

RIBEIRO, Renato Janine. A etiqueta no antigo regime. São Paulo: Brasiliense, 1990.

ROQUET. Alphabeto portuguez ou novo methodo para aprender a ler com muita facilidade e em muito pouco tempo tanto a letra redonda como a manuscripta. Rio de Janeiro: Eduardo e Henrique Laemmert, 1862.

SCHAPOCHNIK, Nelson. Contextos de leitura no Rio de Janeiro do século 19: salões, gabinetes literários e bibliotecas. In: BRESCIANI, Stella. Imagens da cidade: séculos 19 e 20. São Paulo: Anpuh/Marco Zero/Fapesp, 1993, p. 147-162.

SCHEFFLER, I. A linguagem da educação. São Paulo: Saraiva, 1974.

SCHWARTZ, Cleonara Maria. A escola e a construção da subjetividade. Vitória: Edufes, 2000.

SCHWARTZ, Cleonara Maria. Tradicional instituição e ensino de qualidade: representação e imagem da escola normal D. Pedro II nos anos de 1950. São Paulo: USP, 2004. Tese (doutorado em Educação). Faculdade de Educação, Universidade de São Paulo.

SEGUNDO livro de leitura: editado pelos professores da Escola Gratuita São José. 9 ed. Petrópolis: Typographia das Vozes de Petrópolis, 1922.

SILVA, Vivia Batista; GALLEGO, Rita de Cássia. Construções da ideia de criança normal nas escolas primárias brasileiras: uma análise a partir dos manuais pedagógicos entre finais do século 19 e início do 20. Cadernos de História da Educação, v. 10, 2011, p. 1-10.

SILVA, Vivian Batista. Escritos modestos sobre grandes auctores: a produção dos manuais pedagógicos no Brasil e em Portugal (1870-1970). In: PERANDONES, Pablo Celada (ed.). Arte y oficio de enseñar: XVI Coloquio Nacional de Historia de la Educación. El Burgo de Osma: Universidade de Valladolid/Sociedade Española de Historia de la Educación, 2011, p. 201-208.

SNYDERS, Georges. La joie à l'école. Paris: Presses Universitaires de France, 1986.

SOARES, Magda. A linguagem didática. In: NAGLE, Jorge. Educação e linguagem. São Paulo: Edart, 1976, p. 145-160. 
SOARES, Magda. Linguagem e escola: uma perspectiva social. São Paulo: Ática, 1986.

SOUZA, Rosa Fátima. Espaço da educação e da civilização: origens dos grupos escolares do Brasil. In: SOUZA, Rosa Fátima; VALDEMARIN, Vera Teresa; ALMEIDA, Jane Soares. O legado educacional do século 19. Araraquara: Unesp/FCL, 1998, p. 1962.

SOUZA, Rosa Fátima. Templos de civilização: a implantação da escola primária graduada no Estado de São Paulo (1890-1910). São Paulo: Unesp, 1998.

STEPHANOU, Maria. Bem viver em regras: urbanidade e civilidade em manuais de saúde. Educação Unisinos, v. 4, 2006, p. 35-44.

STEPHANOU, Maria. Tratar e educar: discursos médicos nas primeiras décadas do século 20. Porto Alegre: Ufrgs, 1999. 450f. Tese (doutorado em Educação). Faculdade de Educação, Universidade Federal do Rio Grande do Sul.

TANURI, Leonor Maria. História da formação de professores. Rev. Bras. Educ., n. 14, 2000, p. 61-88.

TREVISAN, Thabatha Aline. História da disciplina pedagogia nas escolas normais do Estado de São Paulo (1874-1959). Marília: Unesp, 2011. 350f. Tese (doutorado em Educação). Universidade Estadual Paulista.

TYACK, David; CUBAN, Larry. Tinkering toward utopia: a century in public school reform. London: Harvard University Press, 1995.

VALDEMARIN, Vera Teresa. Estudando as lições de coisas: análise dos fundamentos filosóficos do método do ensino intuitivo. São Paulo: Fapesp/Autores Associados, 2004.

VALDEMARIN, Vera Teresa. História dos métodos e materiais de ensino: a escola nova e seus modos de uso. São Paulo: Cortez, 2010.

VEIGA, Cynthia Greive. A escolarização como projeto de civilização. Revista Brasileira de Educação, n. 21, 2002, p. 90-103.

VENTURA, Duarte. Arte de aprender a ler. Paris: Guillard \& Aillaud, 1888.

VIDAL Diana Gonçalves. Escola nova e processo educativo. In: LOPES, Eliane Marta Teixeira; FARIA FILHO, Luciano Mendes; VEIGA, Cynthia Greive. 500 anos de educação no Brasil. Belo Horizonte: Autêntica, 2000, p. 497-517.

VIDAL, Diana Gonçalves. Culturas escolares: estudo sobre práticas de leitura e escrita na escola pública primária (Brasil e França, final do século 19). Campinas: Autores Associados, 2005.

VIDAL, Diana Gonçalves. O exercício disciplinado do olhar: livros, leituras e práticas de formação docente no Instituto de Educação do Distrito Federal (1932-1937). São Paulo: USP, 1995. 343f. Tese (doutorado em Educação). Faculdade de Educação, Universidade de São Paulo.

VIDAL, Diana Gonçalves. Livros por toda parte: o ensino ativo e a racionalização da leitura nos anos 1920 e 1930 no Brasil. In: ABREU, Márcia (org.). Leitura, história e história da leitura. Campinas: Mercado de Letras: Associação de Leitura do Brasil/ Fapesp, 1999, p. 335-355.

VIÑAO FRAGO, Antonio. Do espaço escolar e da escola como lugar: propostas e questões. In: FRAGO, Antonio Viñao; ESCOLANO, Agustin. Currículo, espaço e subjetividade: a arquitetura como programa. Rio de Janeiro: DP\&A, 1998a, p. 59-139.

VIÑAO FRAGO, Antonio. History of education and cultural history: possibilities, problems, questions. In: POPKEWITZ, Thomas S; PEREYRA, Miguel A; FRANKLIN, Barry M; 
POPKEWITZ, Thomas S; PEREYRA, Miguel A; FRANKLIN, Barry M. Cultural history and education. New York: Routlegdefalmer, 2001, p. 125-150.

VIÑAO FRAGO, Antonio. Tiempos escolares, tiempos sociales: la distribución del tiempo e del trabajo en la enseñanza primaria en España (1838-1936). Barcelona: Ariel, 1998b.

VINCENT, Guy. L'école primaire française: étude sociologique. Lyon: Presses Universitaires de Lyon/Editions de la Maison des Sciences de l'Homme, 1980.

VINCENT, Guy. L'éducation prisionniére de la forme scolaire: scolarisatino et socailisation dans les societés industrielles. Lyon: Presses Universitaires de Lyon, 1994.

WARDE, Miriam Jorge; CARVALHO, Marta Maria Chagas. Política e cultura na produção da história da educação no Brasil. In: WARDE, Miriam Jorge (org.). Contemporaneidade e educação, v. 5, n. 7, 2000, p. 9-33.

WARDE, Mirian Jorge; CARVALHO, Marta Maria Chagas. Politics and culture in the making of history of education in Brazil. In: POPKEWITZ, Thomas S; PEREYRA, Miguel A; FRANKLIN, Barry M. POPKEWITZ, Thomas S; PEREYRA, Miguel A; FRANKLIN, Barry M. Cultural history and education. New York: Routlegdefalmer, 2001, p. 93-104.

XAVIER, Libânia Nacif; CARVALHO, Marta Maria Chagas; MENDONÇA, Ana Waleska (orgs.). Escola, cultura e saberes. Rio de Janeiro: FGV, 2005.

CARLOTA BOTO é professora associada na Faculdade de Educação da Universidade de São Paulo, onde leciona Filosofia da Educação. É bolsista produtividade PQ2 do CNPq. Formou-se na USP, em Pedagogia (1983,) e em História (1988). É mestre em História e Filosofia da Educação pela FEUSP (1990), doutora em História Social pela FFLCH/USP (1997) e livre-docente em Filosofia da Educação pela FEUSP (2011).

Endereço: Alameda Franca, 260/102 - 01422-000 - São Paulo - SP - Brasil.

E-mail: reisboto@usp.br.

Recebido em 19 de março de 2014.

Aceito em 13 de junho de 2014. 